\title{
Microstructure Characteristics of Fly Ash Concrete with Rice Husk Ash and Lime Stone Powder
}

\author{
Sang-Hwa Jung1), Velu Saraswathy ${ }^{2)}$, Subbiah Karthick ${ }^{3)}$, Palanivel Kathirvel ${ }^{4}$, \\ and Seung-Jun Kwon ${ }^{5), *}$ (B)
}

(Received September 18, 2017, Accepted February 6, 2018)

\begin{abstract}
Industrial wastes and recycled materials are being utilized in the construction industry for preserving the environment, saving of materials, and enhancing durability of the construction material. Blending of cement with supplementary cementitious materials like fly ash, rice husk ash, and silica fume makes concrete more durable. The main objective of this study is to make use of the rice husk ash and lime powder (LP) as a replacement of Portland pozzolana cement considering various replacement levels. The engineering and durability performance in concrete with LP were performed through compressive strength and void measurement. The microstructure in the concrete with LP was characterized through XRD, SEM/EDS, and TG/DTA. Optimum replacement ratio for rice husk ash and LP were obtained through pozzolanic reaction based CSH formation.
\end{abstract}

Keywords: portland pozzolana cement, fly ash, rice husk ash, limestone powder, microstructure.

\section{Introduction}

Addition of LP to cement causes an increase of hydration at early ages inducing a high early strength, but it can reduce the long-term strength due to the dilution effect (Ghrici et al. 2007). RHA could be advantageously blended with OPC without adversely affecting the strength and permeability properties of concrete due to the pozzolanic reaction and packing effect (Ganesan et al. 2008). Addition of RHA to OPC not only improves the early strength of the concrete but also forms a calcium silicate hydrate $(\mathrm{CSH})$ gel around cement particles, which leads to the highly dense pore structure (Saraswathy and Song 2007). Pozzolana, FA, GGBFS (Ground Granulated Blast Furnace Slag), LP are the main materials permitted by the European Standards EN 197-1(2000) (European committee 2000).

\footnotetext{
${ }^{1)}$ Korea Conformity Laboratories, Gasandong, Seoul 08503, South Korea.

${ }^{2)}$ Corrosion and Materials Protection Division, CSIRCentral Electrochemical Research Institute, Karaikudi, Tamil Nadu 630003, India.

${ }^{3)} \mathrm{PG}$ and Research Department of Chemistry, Alagappa Government Arts College, Karaikudi, Tamilnadu 630003, India.

${ }^{4)}$ Civil Engineering, Kamaraj College of Engineering and Technology, Virudhunagar, Madurai 625701, India.

${ }^{5)}$ Department of Civil and Environmental Engineering, Hannam University, Daejeon 34430, South Korea.

*Corresponding Author; E-mail: jjuni98@hannam.ac.kr Copyright (C) The Author(s) 2018. This article is an open access publication
}

The increase in the early strength of the mortar due to LP addition and dolomitic limestone can be attributed to their active participation in cement hydration and filler effect of their fine particle size (Voglis et al. 2005; Matschei et al. 2007). The additional surface area by the limestone particles may provide sites for the nucleation and growth of hydration products, which leads to enhancement of strength and durability (Matschei et al. 2007; Bentz 2008). LP addition affects the pore structure of the cement paste. It is reported that LP addition linearly increases the size of capillary pores $(20-40 \mathrm{~nm})$ and due to the high silica content, RHA is said to be an extremely reactive pozzolana (Pipilikaki and BeaziKatsioti 2009; Xu et al. 2015; Park et al. 2016). Up to $20 \%$ of the cement may potentially be substituted by LP (or other fillers) to economize on the usage of OPC clinker and to reduce the energy/deleterious emissions associated with its production (Irassar 2009).

RHA addition to OPC not only improves the early strength of concrete but also forms a CSH (Calcium Silicate Hydrate) gel around the cement particles which is highly dense and less porous, which can increase the cracking resistance (Saraswathy and Song 2007). RHA can be produced with varying pozzolanic activity index depending on the degree of grinding and the burning temperature. Up to $40 \%$ replacement of RHA can be adopted with no significant changes in strength characteristics and its effect on volume changes is within the limit specified in the American Standard (Al-Khalaf and Yousif 1984). The quickly cooled RHA from burning for $12 \mathrm{~h}$ at $500{ }^{\circ} \mathrm{C}$ has the highest amount of silanol groups, and it is favorable to be used as pozzolanic cement additive (Nair et al. 2008). Another advantage of RHA is durability enhancement and reasonable compatibility with OPC. 
The use of a blend of equal weight portion of FA and RHA produces a good strength and resistance to chloride ion penetration with less requirement of super-plasticizer (Chindaprasirt et al. 2008). Rice husk after heat treating at $700{ }^{\circ} \mathrm{C}$ for $6 \mathrm{~h}$ produces the amorphous silica which can be used as an additive in concrete as a replacement of cement (Della et al. 2002). Amorphous silica presence is concentrated on the internal and external surfaces of the uncalcinated husk which may promote a pozzolanic action on the surface of the husk and hence enable its use in lightweight concrete (Jauberthie et al. 2000). The pozzolanic effect is reported to be stronger in the binary and ternary mixtures with RHA in proportions of $25 \%$ or higher (Isaia et al. 2003).

The present investigation aims at evaluating the FA cement with RHA and LP as additives, and to characterize the microstructural properties by adapting various analytical techniques such as, X-ray Diffraction (XRD), scanning electron microscope/energy dispersive spectroscopy (SEM/ EDS), and thermogravimetric/differential thermal analysis (TG/DTA). In addition, strength and porosity measurements were also carried out.

\section{Experiment Program}

\subsection{Material Properties}

\subsubsection{Cement and Aggregates}

PPC 53 Grade as per IS 8112-1989 with specific gravity 3.10 is used and the initial/final setting times for cement are 30 and $600 \mathrm{~min}$ respectively. The percentage of cement particles passing through IS $90 \mu$ sieve is $96.4 \%$. The chemical composition of FA cement is given in Table 1. Fine Aggregate used is river sand passing through $2.36 \mathrm{~mm}$ sieve, falling under zone III as specified in IS 383-1978 and with specific gravity 2.60. Coarse aggregates with specific gravity 2.60 graded with angular aggregates of varying size between 4.75-16 mm was used. The mix proportion for M30 concrete arrived by IS code is given in Table 2 .

\subsubsection{Rice Husk Ash}

Locally available rice husk was treated at $700{ }^{\circ} \mathrm{C}$ for $3 \mathrm{~h}$, and the ash is taken for the investigation. The obtained ash is a grey color, with the mean particle size of $25 \mu \mathrm{m}$, and specific gravity of 2.3 . The chemical composition of RHA is given in Table 3. The Specific gravity and surface area of RHA are 2.23 and $85 \mathrm{~m}^{2} / \mathrm{g}$ respectively.

\subsubsection{Lime Powder (LP)}

LP was used for the study, and purchased from limestone kiln industries. The particle size distribution of LP is shown in Fig. 1. The average particle size of the LP varies from 10 to $100 \mu \mathrm{m}$, with about $10 \%$ less than $1 \mu \mathrm{m}$. This fineness of LP makes readily react to give the early strength of the concrete. The major frequency lies within particle size of $40 \mu \mathrm{m}$ to $50 \mu \mathrm{m}$. Chemical composition of LP is $\mathrm{CaO}$ $93.1 \%, \mathrm{MgO} 1.6 \%, \mathrm{SiO}_{2} 1.3 \%, \mathrm{MnO}_{3} 1.2 \%$, and $\mathrm{CaCO}_{3}$ $2.8 \%$.

\subsection{Mixing Systems}

The various mix systems used are given in Table 4. The mix systems were carefully selected based on the preliminary studies by conducting compressive strength test (Kathirvel et al. 2013). Unit weight of cement is given in Table 3. FA cement is replaced with RHA and LP in the following proportions as shown in Table 4.

Table 1 Chemical compositions of PPC (FA cement).

\begin{tabular}{c|c}
\hline Compound & FA cement $(\%)$ \\
\hline Silicon-di-oxide $\left(\mathrm{SiO}_{2}\right)$ & 32.0 \\
\hline Aluminium oxide $\left(\mathrm{Al}_{2} \mathrm{O}_{3}\right)$ & 10.0 \\
\hline Ferric oxide $\left(\mathrm{Fe}_{2} \mathrm{O}_{3}\right)$ & 6.0 \\
\hline Calcium oxide $(\mathrm{CaO})$ & 44 \\
\hline Magnesium oxide $(\mathrm{MgO})$ & 2.0 \\
\hline Sulphur tri oxide $\left(\mathrm{SO}_{3}\right)$ & 2.5 \\
\hline Loss on ignition & 3.5 \\
\hline
\end{tabular}

Physical properties

\begin{tabular}{c|c}
\hline Pozzolonic material used (fly ash \%) & 20 \\
\hline 28 days compressive strength & 48 \\
\hline Fineness $\left(\mathrm{m}^{2} / \mathrm{Kg}\right)$ & 363 \\
\hline Specific gravity & 2.936 \\
\hline Specific surface area (Blaine) $\left(\mathrm{cm}^{2} / \mathrm{g}\right)$ & 4928 \\
\hline Relative absorption $(\%)$ & 13.25 \\
\hline
\end{tabular}


Table 2 Mix proportion for M30 concrete arrived by IS code method.

\begin{tabular}{c|c|c|c|c}
\hline Materials $/ \mathrm{m}^{3}$ of concrete & Water & Cement & Fine aggregate & Coarse aggregate \\
\hline \hline $\mathrm{kg} / \mathrm{m}^{3}$ & 191.6 & 399 & 540 & 1175 \\
\hline Mix ratio & 0.48 & 1 & 1.353 & 2.944 \\
\hline
\end{tabular}

Table 3 Chemical composition of RHA.

\begin{tabular}{c|c|c|c|c|c|c|c|c|c|c|c}
\hline \multirow{2}{*}{ Ratio } & \multicolumn{2}{|c|}{$\mathrm{SiO}_{2}(91.79 \%)$} & $\mathrm{Al}_{2} \mathrm{O}_{3}$ & $\mathrm{Fe}_{2} \mathrm{O}_{3}$ & $\mathrm{CaO}$ & $\mathrm{MgO}$ & $\mathrm{Na}_{2} \mathrm{O}$ & $\mathrm{K}_{2} \mathrm{O}$ & Others & LOI & Total \\
\cline { 2 - 11 } & $\mathrm{R}^{*}$ & $\mathrm{NR} *$ & & & & & & & & \\
\hline \hline$\%$ & 90.21 & 1.58 & 2.12 & 0.80 & 1.27 & 0.67 & 0.14 & 0.76 & 0.89 & 1.56 & 100 \\
\hline
\end{tabular}

$* R$ reactive, $N R$ non-reactive.

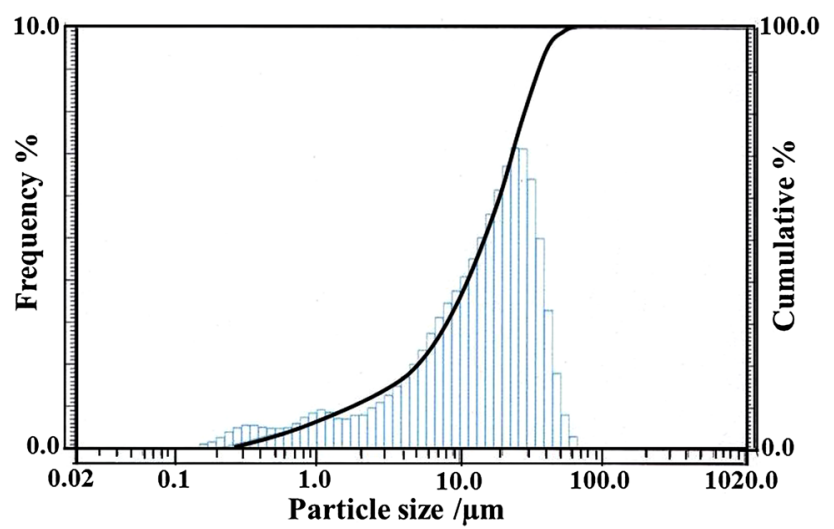

Fig. 1 Particle size distribution for LP.

\subsection{Property Evaluation Tests 2.3.1 Compression Test}

The compressive strength of the concrete is carried out as per IS 516-1959. Concrete cube specimens of size $150 \times 150 \times 150 \mathrm{~mm}^{3}$ are cast with different types of mix systems. After $24 \mathrm{~h}$, the specimens are demolded and subjected to curing for 28 days in water. After 28 days of watersubmerged curing, the cubes are tested in the compressiontesting machine (200T) capacity at the rate of $140 \mathrm{kN} / \mathrm{min}$ as per IS 456-2000. The ultimate load at which the cube fails is taken. Tests are carried out on triplicate specimens and the average compressive strength values are noted.

\subsubsection{Tests for Density and Permeable Voids}

The tests are performed based on ASTM C 642-97 by an oven-drying method. For this test, $50 \mathrm{~mm}$ diameter and $50 \mathrm{~mm}$ height cylindrical specimens are cast. After $24 \mathrm{~h}$ of demolding, the specimens are kept immersed in water. At the end of 28 days, the specimens are taken from the curing tank and air-dried to remove the surface moisture. Then, the specimens are dried in an oven at a temperature of $110^{\circ} \mathrm{C}$ for $48 \mathrm{~h}$, and allowed to cool at room temperature. At the end of $48 \mathrm{~h}$ of cooling, the weights of the specimens are measured with $1 \mathrm{~g}$ accuracy. After that, the specimens are kept immersed in water continuously for $48 \mathrm{~h}$. After $48 \mathrm{~h}$. The increase in weight is measured after wiping out the surface water using the dry cloth. Then the specimens are immersed in water and heated continuously for a period of $5 \mathrm{~h}$. Then the weights of the specimens are taken after a time gap of $14 \mathrm{~h}$. The specimens are suspended in water, and its submerged weight is determined.

To determine the percentage of total voids, the apparent specific gravity of the specimen must be determined. From the above data, water absorption percentage, permeability percentage, and percentage of total voids are determined by adopting the following procedures.

$$
\begin{aligned}
& W_{p}=[(B-A) / A] \times 100 \\
& P_{p}=[(C-A) /(C-D) \times 100] \\
& V_{p}=\left[\left(g_{1}-g_{2}\right) / g_{3}\right] \times 100
\end{aligned}
$$

Table 4 Mix systems.

\begin{tabular}{c|c}
\hline Mix designations & Systems \\
\hline FAC & Fly ash cement \\
\hline FRL5 & Replacement of $+5 \%$ RHA $+5 \%$ LP \\
\hline FRL10 & Replacement of $+10 \%$ RHA $+10 \%$ LP \\
\hline FRL15 & Replacement of $+15 \%$ RHA + 15\% LP \\
\hline FRL20 & Replacement of $+20 \%$ RHA + 20\% LP \\
\hline FRL5-20 & Replacement of $+5 \%$ RHA $+20 \%$ LP \\
\hline FRL10-20 & Replacement of $+10 \%$ RHA $+20 \%$ LP \\
\hline FRL15-20 & Replacement of $+15 \%$ RHA $+20 \%$ LP \\
\hline
\end{tabular}


where $W_{p}$ is water absorption percentage (\%), $A$ is the weight of oven dried sample in air, $B$ is the weight of the surface dry sample in air after immersion in water. $P_{p}$ denotes the permeability percentage (\%), $C$ and $D$ are the weight after $5 \mathrm{~h}$ heated and submerged weight in water, respectively. $V_{p}$ is the percentage of total voids. $g_{1}$ and $g_{2}$ are the results of $\mathrm{A} /(\mathrm{C}-\mathrm{D})$ and apparent specific gravity of the specimens, respectively.

\subsection{Characterization Techniques \\ 2.4.1 XRD and SEM/EDS}

The samples are crushed mechanically, and mineralogical analysis is carried out using XRD with source $\mathrm{CuK} \alpha$ radiation $(\lambda=1.54059 \AA)$ generated at $40 \mathrm{kV}$ and $20 \mathrm{~A}$, was used for the recording of XRD patterns. The identification of diffraction peaks was performed by employing 'peak search' and 'search match' programs in the software (PA Analytical, $\mathrm{X}$ 'pert High score plus). SEM/EDS are also performed for chemical composition measurement. At the end of the exposure period, center core samples are taken and subjected to SEM/EDS analysis for identification of elements present in the concrete samples.

\subsubsection{Thermogravimetry and Differential Thermal} Analysis

TG/DTA are performed using a simultaneous thermo-analyzer with alumina crucibles and holed lids. The heating

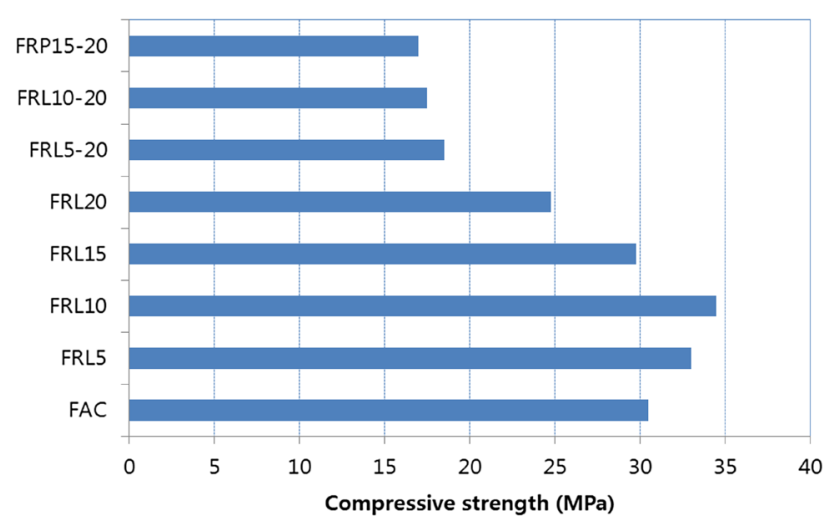

Fig. 2 Compressive strength variation of various systems of concrete. elevation is controlled from ambient temperature to $1000{ }^{\circ} \mathrm{C}$ with static air atmosphere and $20^{\circ} \mathrm{C} / \mathrm{min}$ of heating rate.

\section{Results and Discussion}

\subsection{Compression Test}

Compressive strength variations in concrete with various mixing systems are presented in Fig. 2. From the figure, it is seen that FRL5 and FRL10 have shown better/higher compressive strength than the control (FAC) and other systems. The increase in strength is 8.2 and $14.75 \%$ higher than the control specimen. Other systems (FRL15 and FRL 201) have shown the reduction in compressive strength values than the control specimens.

The increase in compressive strength at 5 and $10 \%$ replacement level of RHA and LP is due to the pozzolanic action of RHA combined with LP accelerated the strength formation (Walker and Pavia 2011). Since $\mathrm{Ca}(\mathrm{OH})_{2}$ reacts in solution with atmospheric carbon dioxide $\mathrm{CO}_{2}$ to form calcium carbonate or calcite, $\mathrm{CaCO}_{3}$ which is significantly stronger and less soluble than the portlandite, enhanced the strength formation (Johannesson and Utgenannt 2001). More addition of LP and RHA results in a reduction of strength. The strength reduction in FRL5-10, FRL10-20, and FRL15-20 may be due to the insufficient alkali activation in the presence of LP. The systems FAC, FRL5, FRL10, FRL15, and FRL20 have shown the reasonable strength development; thereby the microstructural studies have been carried out for these five systems.

\subsubsection{Tests for Density, Permeable Voids and Water Absorption}

Table 5 represents the volume of permeable voids for various systems. From the table, it is found that FRL5 and FRL10 systems are found to have lesser permeable voids when compared to the other three systems (FAC, FRL15, and FRL20). This is due to the fact that the LP reacts with RHA forming a durable CSH gel which reduces the permeable voids in FRL5 and FRL10. As the percentage of RHA and LP increases, the permeable voids also increase. This is due to the precipitation of $\mathrm{CaCO}_{3}$ through reaction with $\mathrm{Ca}(\mathrm{OH})_{2}$ and $\mathrm{CO}_{2}$. The formation of $\mathrm{CaCO}_{3}$ changes the microstructure of the mortar, also affecting the pore

Table 5 Volume of permeable voids for various systems.

\begin{tabular}{c|c|c|c|c|c|c|c}
\hline Mix systems & $\begin{array}{c}\text { Absorption after } \\
\text { immersion } \\
(\mathrm{B}-\mathrm{A}) / \mathrm{A} \times 100 \\
(\%)\end{array}$ & $\begin{array}{c}\text { Absorption after } \\
\text { immersion and } \\
\text { boiling }(\mathrm{C}-\mathrm{A}) / \\
\mathrm{A} \times 100(\%)\end{array}$ & $\begin{array}{c}\text { Bulk density, dry } \\
\mathrm{A} / \mathrm{C}-\mathrm{D}) \times \rho \\
{\left[\mathrm{g}_{1}\right]\left(\mathrm{mg} / \mathrm{m}^{3}\right)}\end{array}$ & $\begin{array}{c}\text { Bulk density } \\
\text { after immersion } \\
\mathrm{B} /(\mathrm{C}-\mathrm{D}) \times \rho\end{array}$ & $\begin{array}{c}\text { Bulk density } \\
\text { after immersion } \\
\text { and boiling } \mathrm{C} / \\
(\mathrm{C}-\mathrm{D}) \times \rho\end{array}$ & $\begin{array}{c}\text { Apparent density } \\
\mathrm{A} /(\mathrm{A}-\mathrm{D}) \times \rho \\
{\left[\mathrm{g}_{2}\right]}\end{array}$ & $\begin{array}{c}\text { Volume of } \\
\left(\mathrm{mg} / \mathrm{m}^{3}\right)\end{array}$ \\
$\begin{array}{c}\text { permeable voids } \\
(\%)\left[\left(\mathrm{g}_{2}-\mathrm{g}_{1}\right) /\right. \\
\left.\mathrm{g}_{2}\right] \times 100\end{array}$ \\
\hline \hline FAC & 8.914 & 8.706 & 1.986 & 2.163 & 2.159 & 2.402 & 17.294 \\
\hline FRL5 & 8.109 & 8.271 & 1.965 & 2.125 & 2.128 & 2.347 & 16.256 \\
\hline FRL10 & 8.585 & 8.647 & 1.988 & 2.159 & 2.160 & 2.401 & 17.192 \\
\hline FRL15 & 10.431 & 11.531 & 1.968 & 2.174 & 2.195 & 2.546 & 22.697 \\
\hline FRL20 & 9.188 & 10.398 & 1.938 & 2.116 & 2.139 & 2.427 & 20.149 \\
\hline
\end{tabular}




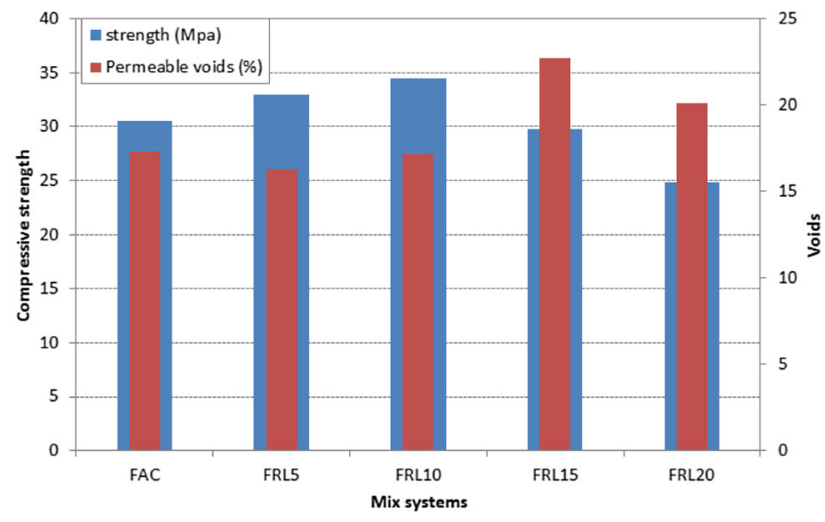

Fig. 3 Strength and permeable voids of various mix systems.

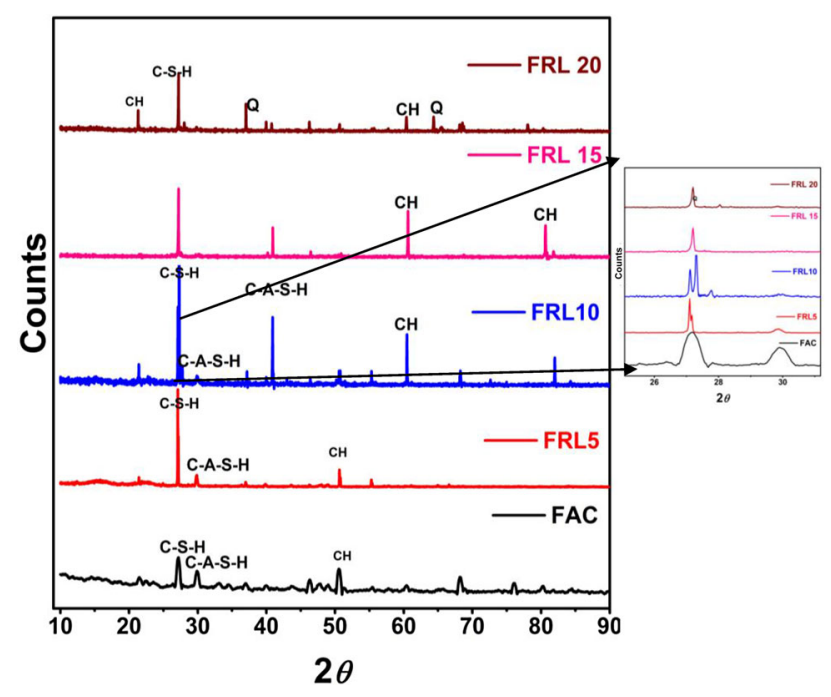

Fig. 4 XRD Pattern for Various mix of concrete.

structure. If PPC is used as a binder, voids are expected to decrease in RHA and LP addition due to the formation of dense CSH which causes the pore size refinement.
The compressive strength and permeable voids are presented in Fig. 3. From the figure, it is observed that the percentage volume of permeable voids is found to be less for 5 and 10\% blending with RHA and LP and increases with the further replacement of 15 and $20 \%$ LP. From the studies, it is observed that $10 \%$ blending is found to be the critical percentage of cement replacement. Beyond 10\% blending, there is an increase in the volume of permeable voids due to the leaching of LP (unreacted) or higher formation of $\mathrm{Ca}(\mathrm{OH})_{2}$ which is confirmed by XRD studies.

\subsection{Characterization Techniques 3.2.1 X-ray Diffraction}

Figure 4 shows the XRD pattern of various mix systems FAC, FRL5, FRL10, FRL15 and FRL20. All diffraction peaks present in the figures are coinciding with JCPDFWIN data. The XRD pattern of FAC shows diffraction peaks at $27.03^{\circ}$ and $29.86^{\circ}$ corresponding to $\mathrm{C}-\mathrm{S}-\mathrm{H}\left(\mathrm{Ca}_{2} \mathrm{SiO}_{4}\right)$ and $\mathrm{C}-\mathrm{A}-\mathrm{S}-\mathrm{H}\left(\mathrm{Ca}\left[\mathrm{Al}_{2} \mathrm{Si}_{2} \mathrm{O}_{8}\right]\right)$. The other intensity peak at $50.5^{\circ}$ is corresponding to $\mathrm{CH}$ (ettringite). The XRD Pattern of FRL5 and FRL10 shows the high intensity peaks of $\mathrm{C}-\mathrm{S}-\mathrm{H}$ $\left(\mathrm{Ca}_{2} \mathrm{SiO}_{4}\right)$ and $\mathrm{C}-\mathrm{A}-\mathrm{S}-\mathrm{H}\left(\mathrm{Ca}\left[\mathrm{Al}_{2} \mathrm{Si}_{2} \mathrm{O}_{8}\right]\right)$ when compared to FAC system. The XRD pattern of FRL15 and FRL20 shows the newer peaks at $60.7^{\circ}$ and $64.7^{\circ}$ corresponding to the $\mathrm{CH}$ and quartz $\left(\mathrm{SiO}_{2}\right)$ due to the excess amount of unreacted LP and RHA.

\subsubsection{SEM and EDS}

Figure 5 shows the SEM image of FAC in which small and larger particles are seen along with white crystals of unhydrated calcium hydroxide platelets are observed in the matrix along with small CSH fibers, which cover the anhydrous grains of calcium silicate (Feldman and Sereda 1968). Figure 6 shows the SEM image of 5\% LP $+5 \%$ RHA replaced concrete in which large crystals are loosely packed and covered with white clusters of $\mathrm{Ca}(\mathrm{OH})_{2}$. In FRL5, the hydrates are appearing as a mix of large platelets

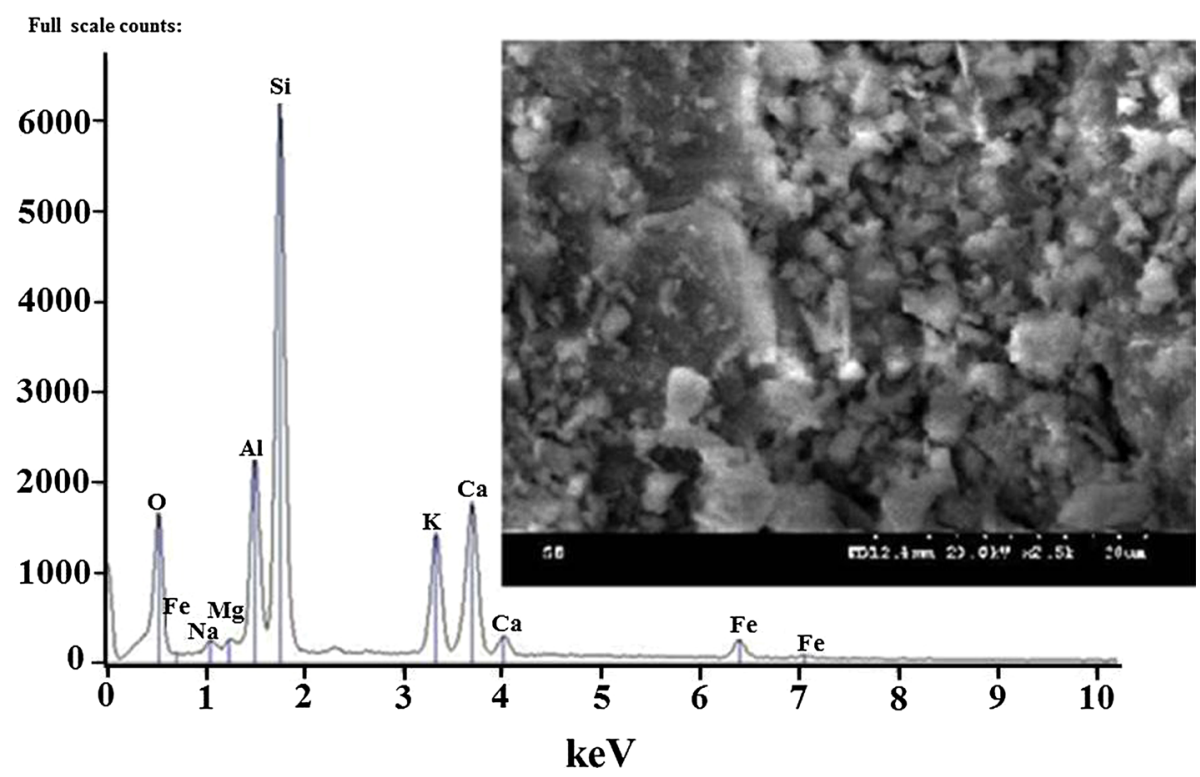

Fig. 5 SEM analysis for FAC. 


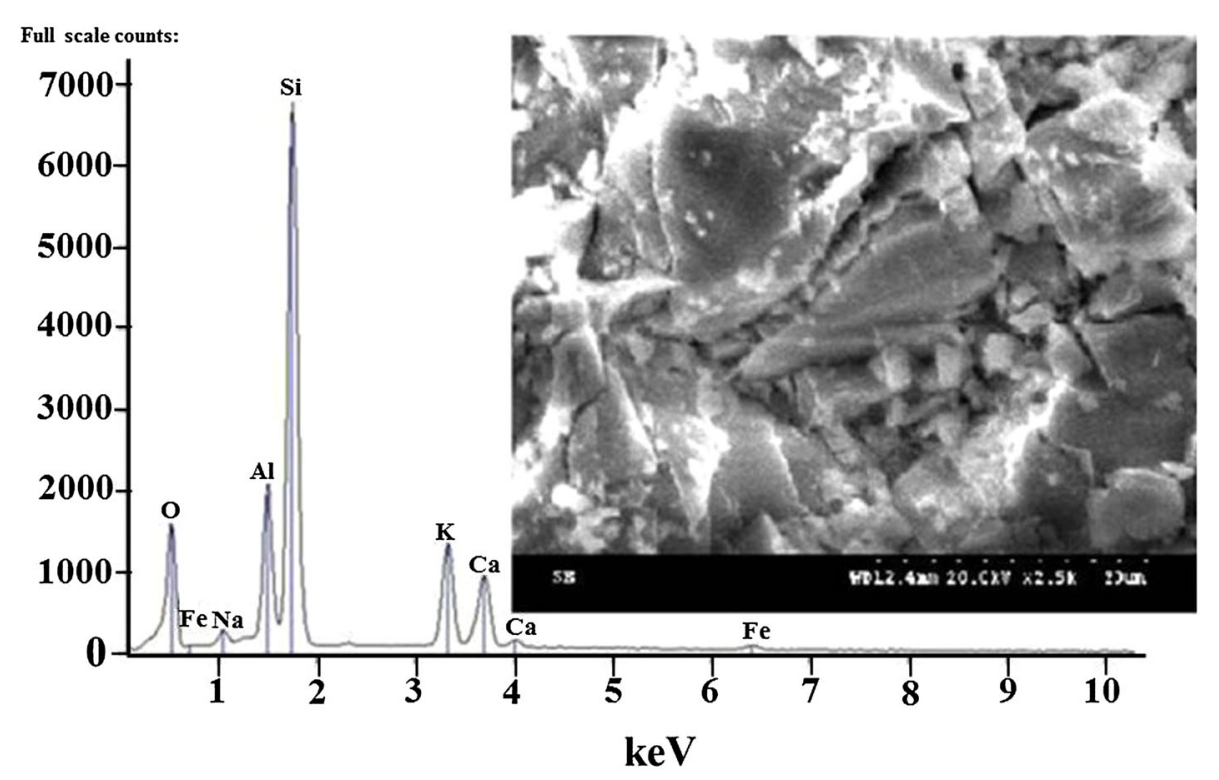

Fig. 6 SEM analysis for FRL5.

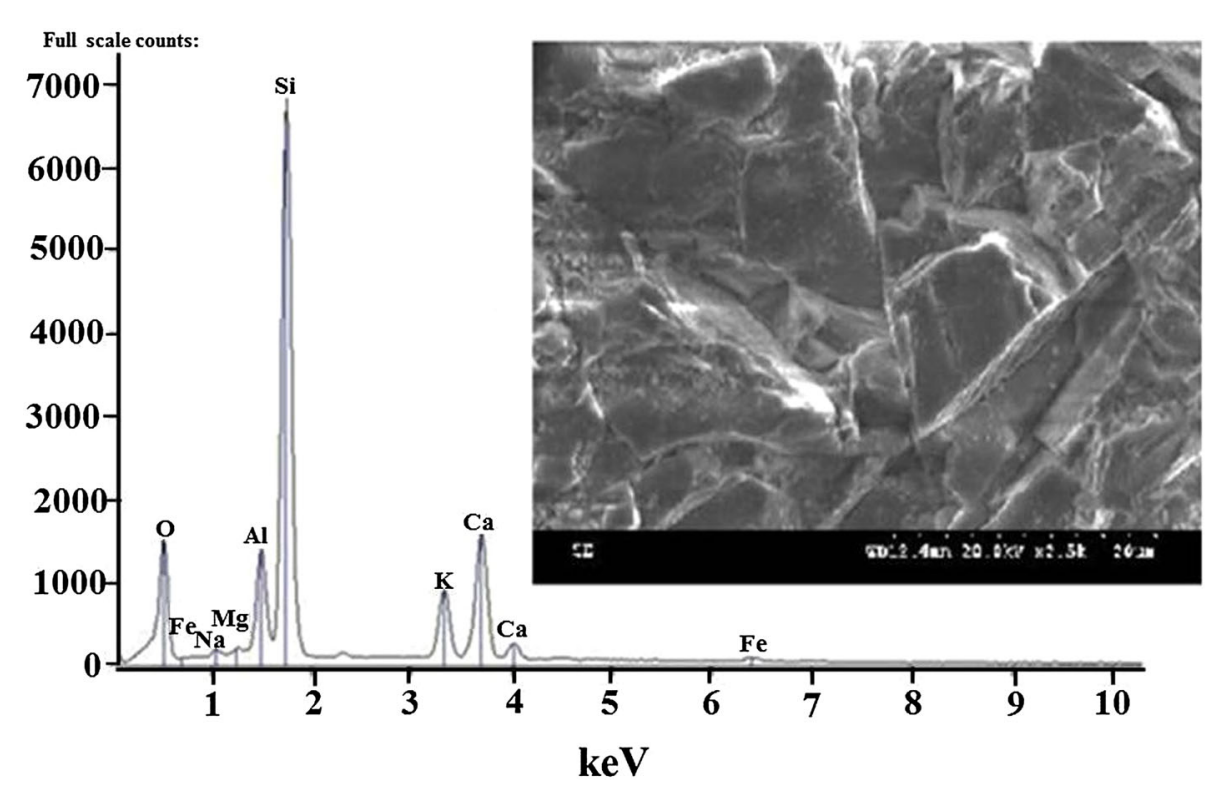

Fig. 7 SEM analysis for FRL10.

and noncontiguous small clusters. In contrast, if the percentage of LP increases over 10\%, micro-cracks have appeared and these cracks in turn make the matrix less compact (Fig. 7). As the replacement of LP and RHA increases, SEM micrographs (Figs. 8, 9) display an altered structure, showing a mix of large platelets and small clusters. In this case, however, the clusters are tightened, which induces lower porosity in the matrix microstructure.

The quantitative results such as calcium, silica, magnesium, and alumina are presented in Fig. 10. It is found that FAC contains $11.61 \%$ of calcium, whereas LP and RHA replaced systems show $6.71 \%$ for FRL5, $11.87 \%$ for FRL10, $23.35 \%$ FRL 15 , and $42.13 \%$ of calcium, respectively. Also, FAC contains $23.54 \%$ of silica, wherein LP and RHA replaced systems show $28.44,28.46,18.28$ and $5.61 \%$ of silica with increasing replacement. In contrast, alumina percentages are gradually decreasing from 7.94 to $0.93 \%$ with increasing LP and RHA. This is strongly evidenced by XRD results that the calcium silicate hydrates are formed up to $15 \%$ of LP and RHA. The major components are plotted in Fig. 10 through EDS analysis.

\subsubsection{Tg/dta}

In DTA curve zone one between 100 and $300{ }^{\circ} \mathrm{C}$ is attributed to the dehydration of $\mathrm{CSH}$ and ettringite (Lee 1974). At this temperature, these compounds lose water, depends upon the available $\mathrm{CaO} / \mathrm{SiO}_{2}$ ratio in the hydrated cement matrix. Zone two from 290 to $350{ }^{\circ} \mathrm{C}$ corresponds to the decomposition of calcium aluminate silicate hydrate, calcium aluminate hydrate and calcium chloroaluminate 


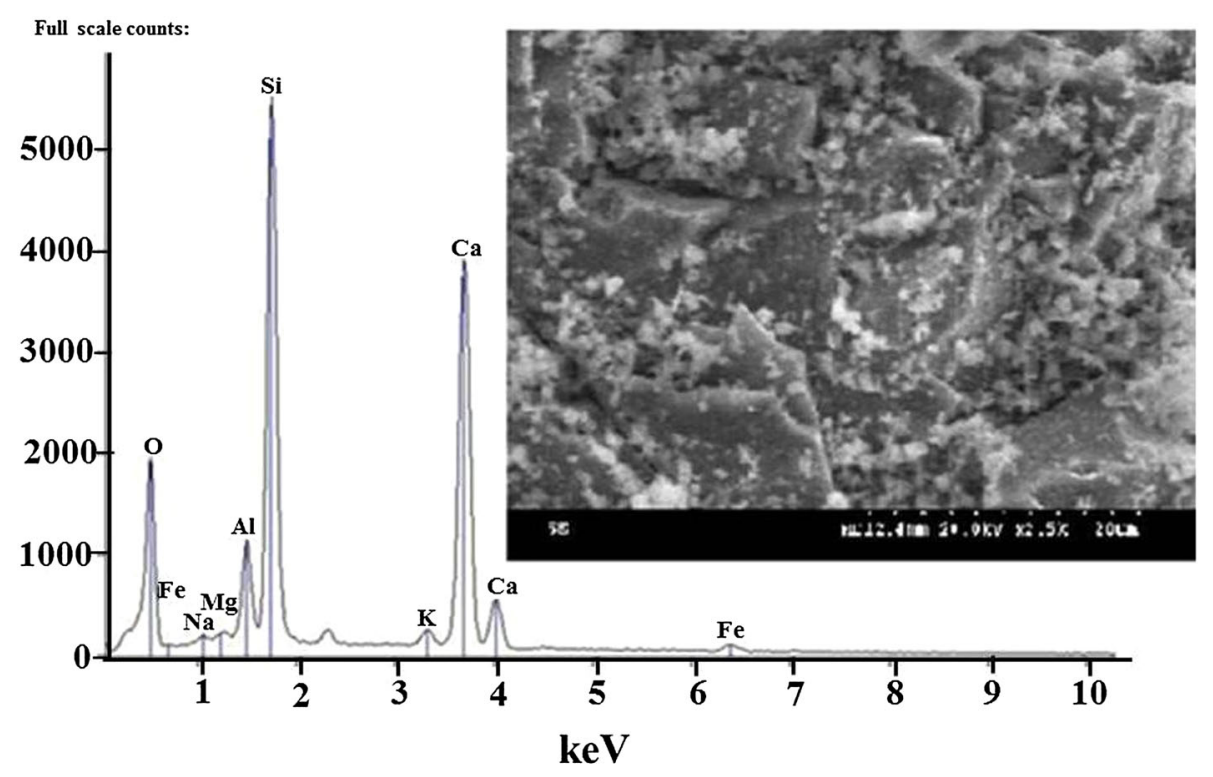

Fig. 8 SEM analysis for FRL15.

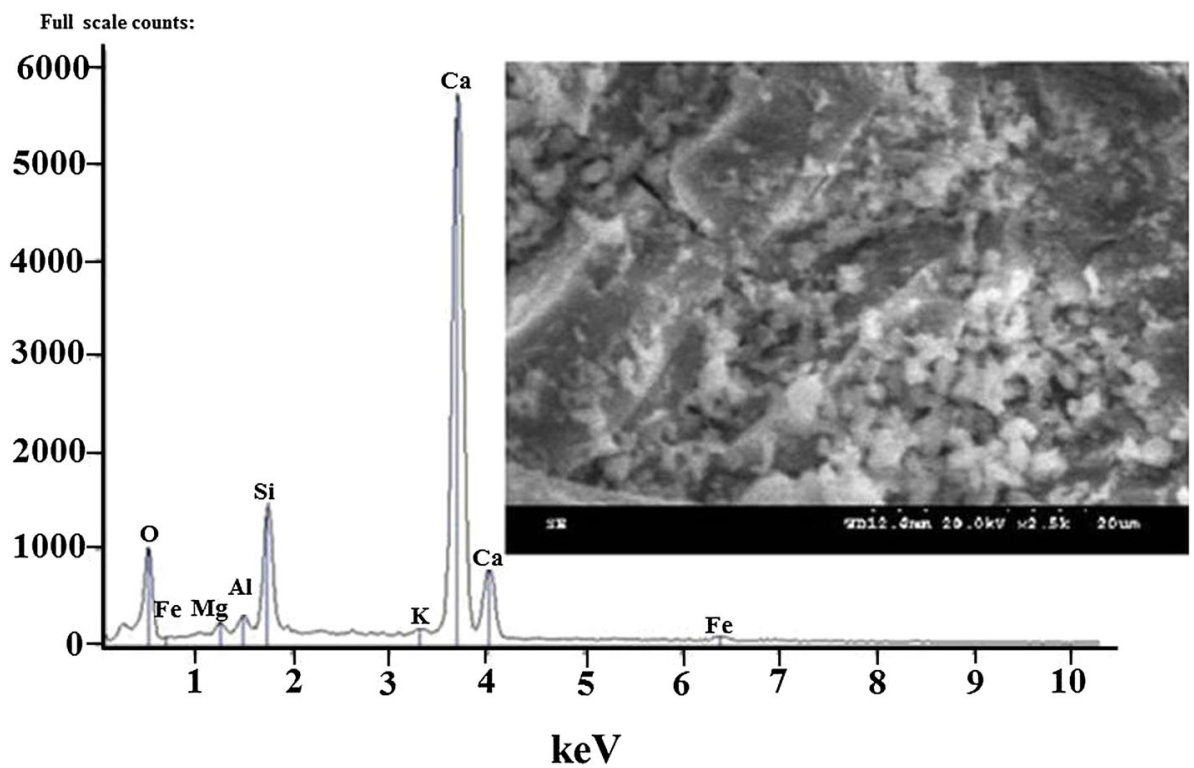

Fig. 9 SEM analysis for FRL20.

(Ubbriaco and Calabrese 1998). The third zone ranging from 450 to $510{ }^{\circ} \mathrm{C}$ is attributed to the dehydration of calcium hydroxide. Decarbonation of calcium carbonate in the hydrated compound starts over $700{ }^{\circ} \mathrm{C}$. The observed weights of $\mathrm{Ca}(\mathrm{OH})_{2}, \mathrm{CSH}$, and $\mathrm{CaCO}_{3}$ are summarized in Table 6.

From the results, it is observed that $\mathrm{Ca}(\mathrm{OH})_{2}$ content is found to decrease with increase in replacement of LP and RHA. However the weight of CSH is found to increase up to $10 \%$ and beyond $10 \%$, there is a decrease in trend observed. The reduction in $\mathrm{Ca}(\mathrm{OH})_{2}$ in blended cement concrete indicates its consumption due to the pozzolanic reaction (Kathirvel et al. 2013). This is the main advantage of using blended cement, which leads to the densification of the

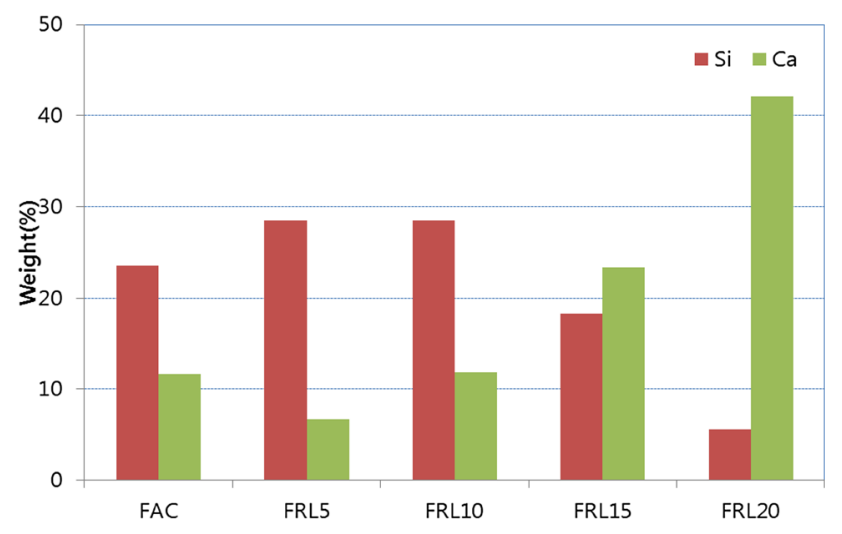

Fig. 10 EDS quantitative results for Si and $\mathrm{Ca}$ (weight \%). 
Table 6 TG/DTA Results for various FAC with increasing RHA and LP.

\begin{tabular}{c|c|c|c}
\hline Results & Wt. of $\mathrm{Ca}(\mathrm{OH})_{2}(\%)$ & Wt. of C-S-H (\%) & Wt. of CaCO $(\%)$ \\
\hline \hline FAC & 3.03 & 9.5 & 0.97 \\
\hline FRL5 & 1.55 & 9.48 & 0.83 \\
\hline FRL10 & 1.50 & 10.48 & 0.97 \\
\hline FRL15 & 1.36 & 9.75 & 1.39 \\
\hline FRL20 & 1.48 & 7.9 & 1.42 \\
\hline
\end{tabular}

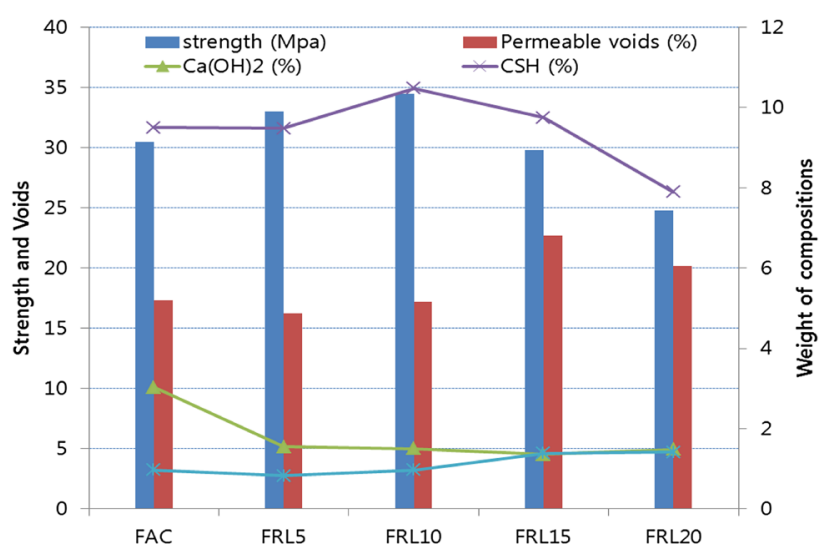

Fig. 11 Results of composition weight with strength and voids.

microstructure. The reduction of $\mathrm{Ca}(\mathrm{OH})_{2}$ content is higher in blended cement concrete than in FAC, indicating more pozzolanic reaction due to the presence of LP.

The main hydrated phases produced during the pozzolanic reaction at ambient temperature are $\mathrm{CSH}, \mathrm{C}_{2} \mathrm{ASH}$ and $\mathrm{C}_{4} \mathrm{AH}$. From the TG/DTA results, the calcium hydrates (CSH) content increases with a replacement of LP and RHA up to $15 \%$ and drops at $20 \%$. This clearly shows that in blended cement concretes in the presence of water, both FA in FAC and silica present in RHA react with $\mathrm{Ca}(\mathrm{OH})_{2}$ to form denser $\mathrm{CSH}$, thereby the porosity gets reduced. The reduced permeability can be evidenced by water absorption results in Sect. 3.1.2. The weights of various compounds are plotted with strength and measured voids in Fig. 11.

\section{Conclusions}

The conclusions on pore structure characteristics of fly ash concrete with rice husk ash and limestone powder are as follows.

1. Various proportions of LP and RHA have been tested by holding the total binder/sand ratio constant. The experimental results have highlighted the improvement of chemical properties and morphology with varying LP and RHA content.
2. Addition of $10 \%$ of RHA and $10 \%$ LP is found to exhibit excellent performance regarding the strength and voids by the accelerated $\mathrm{CSH}$ formation through effective pozzolanic reaction.

3. The substitution of LP shows $\mathrm{Ca}(\mathrm{OH})_{2}$ platelets along with small $\mathrm{CSH}$ fibers, which covers the anhydrous grains of calcium silicate modifying the microstructure of the mortar matrix.

4. The different crystallization of hydrates is observed from ordinary pozzolanic reaction of fly ash. With increasing replacement of cement with LP substitution induces significant modification of the microstructure, which is demonstrated either by the presence of microcracks in the matrix or by an alternative hydrates development in the case of calcium hydroxide.

\section{Acknowledgements}

This research was supported by the Basic Science Research Program through the National Research Foundation of Korea (NRF) funded by the Ministry of Science, ICT, \& Future Planning (No. 2015R1A5A1037548). One of the authors (V.S) thanks the Director, CECRI, and CSIR for the permission to pursue my fellowship at Hanyang University, Korea.

\section{Open Access}

This article is distributed under the terms of the Creative Commons Attribution 4.0 International License (http:// creativecommons.org/licenses/by/4.0/), which permits un restricted use, distribution, and reproduction in any medium, provided you give appropriate credit to the original author(s) and the source, provide a link to the Creative Commons license, and indicate if changes were made.

\section{Compliance with ethical standards}

Conflict of interest The authors declare that there is no conflict of interest regarding the publication of this paper. 


\section{References}

Al-Khalaf, M. N., \& Yousif, H. A. (1984). Use of rice husk ash in concrete. International Journal of Cement Composites and Lightweight Concrete, 6(4), 241-248.

Bentz, D. P. (2008). Modelling the influence of limestone filler on cement hydration using CEMHYD3D. Cement Concrete Composite, 28(2), 124-129.

Chindaprasirt, P., Rukzon, S., \& Sirivivatnanon, V. (2008). Resistance to chloride penetration of blended Portland cement mortar containing palm oil fuel ash, rice husk ash and fly ash. Construction and Building Materials, 22(5), 932-938.

Della, V. P., Kühn, I., \& Hotza, D. (2002). Rice husk ash as an alternate source for active silica production. Materials Letters, 57(4), 818-821.

European Committee for Standardization, Cement. (2000). Composition, specifications and conformity criteria, part 1 : common cements, EN 197-1, EN/TC51/WG 6 rev. 2000.

Feldman, R. F., \& Sereda, P. J. (1968). A new model of hydrated Portland cement paste as deduced from sorptionlength change and mechanical properties. Materials and Structures, 1(6), 509-519.

Ganesan, K., Rajagopal, K., \& Thangavel, K. (2008). Rice husk ash blended cement: Assessment of optimal level of replacement for strength and permeability properties of concrete. Construction and Building Materials, 22(8), $1675-1683$.

Ghrici, M., Kenai, S., \& Said-Mansour, M. (2007). Mechanical properties and durability of mortar and concrete containing natural pozzolana and limestone blended cements. Cement \& Concrete Composites, 29(7), 542-549.

Irassar, E. F. (2009). Sulfate attack on cementitious materials containing limestone filler-a review. Cement and Concrete Research, 39(3), 241-254.

Isaia, G. C., Gastaldini, A. L. G., \& Moraes, R. (2003). Physical and pozzolanic action of mineral additions on the mechanical strength of high-performance concrete. Cement \& Concrete Composites, 25(1), 69-76.

Jauberthie, R., Rendell, F., Tamba, S., \& Cisse, I. (2000). Origin of the pozzolanic effect of rice husks. Construction and Building Materials, 14(8), 419-423.

Johannesson, B., \& Utgenannt, P. (2001). Micro structural changes caused by carbonation of cement mortar. Cement and Concrete Research, 31(6), 925-931.
Kathirvel, P., Saraswathy, V., Karthik, S. P., \& Sekar, A. S. S. (2013). Strength and durability properties of quaternary cement concrete made with flyash, rice husk ash and limestone powder. Arabian Journal of Science and Engineering, 38(3), 589-598.

Lee, F. M. (1974). The chemistry of cement and concrete (4th ed., p. 184). London: Edward Arnold.

Matschei, T., Lothenbach, B., \& Glasser, F. P. (2007). The role of calcium carbonate in cement hydration. Cement Concrete Research, 37(4), 559-564.

Nair, D. G., Fraaij, A., Klaassen, A. A. K., \& Kentgens, A. P. M. (2008). A structural investigation relating to the pozzolanic activity of rice husk. Cement and Concrete Research, 38(6), 861-869.

Park, K. B., Kwon, S. J., \& Wang, X. Y. (2016). Analysis of the effects of rice husk ash on the hydration of cementitious materials. Construction and Building Materials, 105(2), 196-205.

Pipilikaki, P., \& Beazi-Katsioti, M. (2009). The assessment of porosity and pore size distribution of limestone Portland cement pastes. Construction and Building Materials, 23(5), 1966-1970.

Saraswathy, V., \& Song, H.-W. (2007). Corrosion performance of rice husk ash blended concrete. Construction and Building Materials, 21(8), 1779-1784.

Ubbriaco, P., \& Calabrese, D. (1998). Solidification and stabilization of cement paste containing fly ash from municipal waste. Thermochimica Acta, 321(1-2), 143-150.

Voglis, N., Kakali, G., Chaniotakis, E., \& Tsivilis, S. (2005). Portland-limestone cement, their properties and hydration compared to those of other composite cement. Cement Concrete Composites, 27(2), 191-196.

Walker, R., \& Pavia, S. (2011). Physical properties and reactivity of pozzolans, and their influence on the properties of lime-pozzolan pastes. Materials and structures, 44(6), 1139-1150.

Xu, W., Lo, Y. T., Ouyang, D., Memon, S. A., Xing, F., Wang, W., et al. (2015). Effect of rice husk ash fineness on porosity and hydration reaction of blended cement paste. Construction and Building Materials, 89(8), 90-101. 